\title{
Statistic of fuel consumption in test and in natural operation of vehicles
}

The lowering of carbon dioxide emission is world pursuit which is written in international agreement. It concerns all economy sections, especially motorization. In this last case the lowering is essential, since almost all fuel used for powering vehicles comes from nonrenewable resources. Using these fuels means a one-way carbon motion from underground lode to earth atmosphere. This process has to be immediately stopped. For several years there have been taken actions in this direction. There are both legislative and technical actions. However, the reports which were published in 2016 shows that despite the efforts and engagement of considerable means, the effects are mediocre. There has been noticed, that, though the lowering of carbon dioxide emission determined in bench tests has been attained, it is impossible to notice this progress in natural operation of vehicles. The causes of such a state are sought mainly in incompatibility of test conditions to the real operation of vehicles conditions. Assuming that the carbon dioxide emission is (quasi) directly proportional to fuel consumption, in the article there has been proposed the method of solving the problem of removing divergence between test and operational data. There has been suggested the different attitude to bench data analysis and implementation of new calculative procedures in a way to reach the correlation between the test and operating fuel consumption.

Key words: operation of vehicles, test, fuel consumptions

\section{Introduction}

The carbon dioxide emission to atmosphere is constantly increasing, and in the case of car vehicles it happens in the geometrical progress [1].

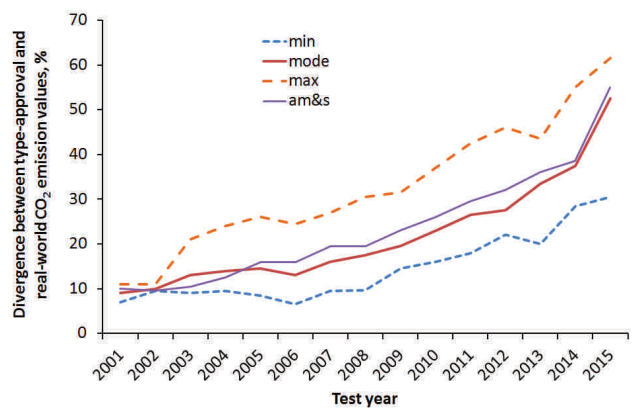

Fig. 1. The increase of carbon dioxide emission from vehicle engines (based on [1])

The increase of carbon dioxide concentration in the atmosphere has to be stopped. Reports published in 2016 shows that despite the efforts and engagement of considerable means, the effects are mediocre. The carbon dioxide emission decrease determined in the bench tests was reached, however, this progress cannot be noticed in the natural operation of vehicles.

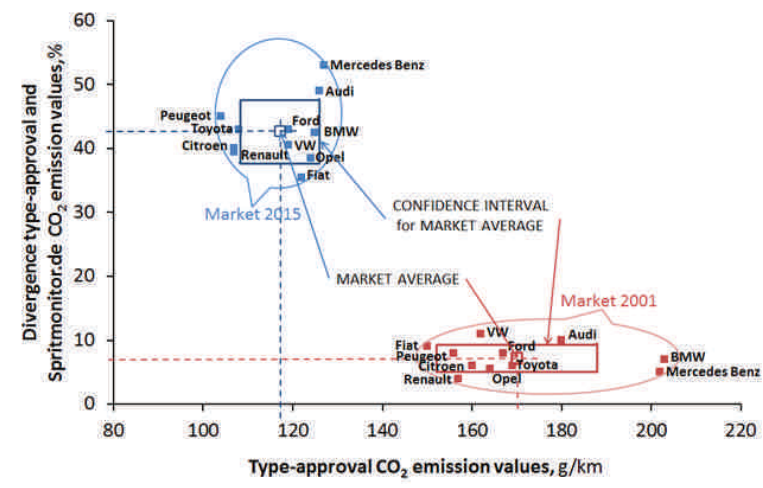

Fig. 2. Test results of carbon dioxide emission in comparison with emission in natural operation (based on [1])

\section{The way of determining of fuel consumption in natural operation}

The way of determining the fuel consumption in natural operation is not regularized in the European Union.

Most often there are measured:

$\mathrm{S}_{\mathrm{m}}$ - vehicle mileage. $\mathrm{km}, \mathrm{OFC}_{\mathrm{sm}}$ - corresponding $\mathrm{S}_{\mathrm{m}}$, operational fuel consumption, $\mathrm{dm}^{3}$, and then there is calculated, $\mathrm{OFC}_{\mathrm{m}}$ - average, operational fuel consumption from the relation:

$$
\mathrm{OFC}_{\mathrm{m}}=100 \cdot \mathrm{OFC}_{\mathrm{sm}} / \mathrm{S}_{\mathrm{m}}
$$

in Europe usually given in $\mathrm{dm}^{3} / 100 \mathrm{~km}$ of the travelled route.

The so-called operational fuel consumption (OFC) is usually determined after multiple travelling over the chosen, test route fragments. The fragments are assigned on the generally available streets and roads. E.g. according to Auto Motor und Sport (AMS) magazine, the determining of fuel consumption is made after traveling the test fragments chosen by the editorial office. The fuel consumption determined in this way is indicated as $\mathrm{OFC}_{\mathrm{Ams}}$. Moreover, AMS also tests vehicles in the conditions of very spare drive (Sparrunde). The fuel consumptions in these conditions is indicated as $\mathrm{OFC}_{\mathrm{AMSs}}$. The fuel consumption determined e.g. from the AMS procedure is not identical with the fuel consumption determined in natural operation. It comes from the fact, that AMS test (as well as other tests of this type) is realized in controlled operation, not in the natural one.

\section{The way of determining the fuel consumption in the test conditions}

Nowadays, in different world regions, there are used the so-called driving tests, realized on the chassis dynamometers where the fuel consumption of the tested vehicles engines is assigned. In Europe it is currently used the NEDC test (New European Driving Cycle), and in The United States the test FTP is used (Federal Test Procedure), etc. In the nearest future the researches are planned according to the new world test. 
The profile of NEDC test velocity presents as follow:

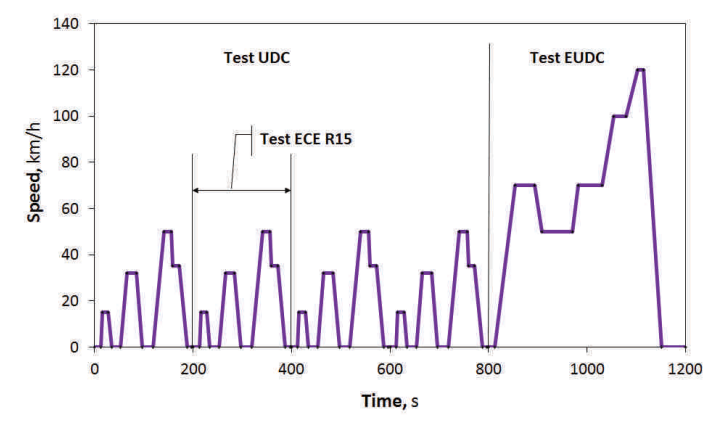

Fig. 3. The profile of NEDC test speed

From the picture it results that the NEDC test is the four time repeated ECE R15 test which is called UDC test (Urban Driving Cycle) plus once repeated EUDC test (Extra Urban Driving Cycle).

The fuel consumption in the NEDC test is determined during vehicle researches in the chassis dynamometer. During researches, the vehicle has to driven in a way that the velocity profile is preserved with very little deviations.

Engines fumes of the researched vehicle are gathered in the special containers ( material bags). Their quantity is logged and the quantity of their particular components is assigned. There is also measured the route that is driven during the test.

The test result concerning the fuel consumption does not comes from the direct measurements but comes from the calculations of the following procedure:

There is assumed that the fuel density is indicated according to EN ISO 12185 ( or other equivalent method), where in case of:

- petrol or gas oil, the density measurement is made in $15^{\circ} \mathrm{C}$;

- LPG and NG - there is used the reference density

○ $0.538 \mathrm{~kg} / \mathrm{dm}^{3}$ in case of LPG

○ $0.654 \mathrm{~kg} / \mathrm{m}^{3}$ in case of $\mathrm{NG}$

If take the indication as follows:

$\mathrm{FC}$ - fuel consumption in $\mathrm{dm}^{3} / 100 \mathrm{~km}$ (liters per $100 \mathrm{~km}$ ) with powering engine by petrol, liquid gas or oil gas or in $\mathrm{m}^{3} / 100 \mathrm{~km}$ ( in case of natural gas), THC - planned hydrocarbon emission in $\mathrm{g} / \mathrm{km}$ of test route, $\mathrm{CO}$ - planned carbon oxide emission in $\mathrm{g} / \mathrm{km}$ of test route, $\mathrm{CO}_{2}-$ planned carbon dioxide emission in $\mathrm{g} / \mathrm{km}$ of the test route, $\mathrm{D}-$ density of the used fuel, then, the fuel consumption assigned in the test comes from the following calculations:

a) in case of the vehicles with spark engines (OTTO) powered with petrol

$$
\begin{aligned}
\mathrm{FC}=(0.1154 / \mathrm{D}) & \times[(0.866 \times \mathrm{THC})+(0.429 \times \mathrm{CO})+ \\
& \left.+\left(0.273 \times \mathrm{CO}_{2}\right)\right]
\end{aligned}
$$

b) in case of vehicles with spark engines (OTTO) powered with LPG

$$
\begin{gathered}
\mathrm{FC}_{\text {norm }}=(0.1212 / 0.538) \times[(0.825 \times \mathrm{THC})+(0.429 \times \\
\left.\times \mathrm{CO})+\left(0.273 \times \mathrm{CO}_{2}\right)\right]
\end{gathered}
$$

If the composition of fuel is different from the standard one then (2) changes into:

$$
\begin{gathered}
\mathrm{FC}_{\text {norm }}=(0.1212 / 0.538) \times \mathrm{c}_{\mathrm{f}} \times[(0.825 \times \mathrm{THC})+(0.429 \times \\
\left.\mathrm{CO})+\left(0.273 \times \mathrm{CO}_{2}\right)\right]
\end{gathered}
$$

$c_{f}$ is assigned from the relation: $c_{f}=0.825+0.0693 \times n_{r}$, where $\mathrm{n}_{\mathrm{r}}-$ actual proportion $\mathrm{H} / \mathrm{C}$ of the used fuel.

c) in case of vehicles with spark engines (OTTO) powered with NG

$$
\begin{gathered}
\mathrm{FC}_{\text {norm }}=(0.1336 / 0.654) \times[(0.749 \times \mathrm{THC})+(0.429 \times \\
\left.\mathrm{CO})+\left(0.273 \times \mathrm{CO}_{2}\right)\right]
\end{gathered}
$$

d) in case of vehicles with compression ignition engine (diesel):

$$
\begin{gathered}
\mathrm{FC}=(0.1155 / \mathrm{D}) \times[(0.866 \times \mathrm{THC})+(0.429 \times \mathrm{CO})+(0.273 \times \\
\left.\left.\times \mathrm{CO}_{2}\right)\right]
\end{gathered}
$$

The fuel consumption assigned in the test is therefore not the result of direct measurement but the recalculations, and is based on the results of the engine fumes components concentration. It has a huge advantage because it enables to release the results from the actual existing chemical composition of fuel. This can, however, lead (and leads) to divergences between the fuel consumption assigned in the tests and in the natural operation.

If we know that emissions of THC and $\mathrm{CO}$ are not more than $1 \%$ of total emissions, then the quasi linear relationship between fuel consumption and $\mathrm{CO}_{2}$ emissions results from the above equations

The basic parameters of NEDC tests are following:

Table 1. The basic parameters of NEDC tests

\begin{tabular}{|l|c|c|c|c|}
\hline \multirow{2}{*}{ Characteristics } & \multirow{2}{*}{ Unit } & \multicolumn{3}{|c|}{ Test } \\
\cline { 3 - 5 } & & ECE & EUDC & UDC+EUDC=NEDC \\
\hline Route & $\mathrm{km}$ & 1.013 & 6.955 & $4 \times 1.013+6.955=11.007$ \\
\hline Duration & $\mathrm{s}$ & 195 & 400 & $4 \times 195+400=1180$ \\
\hline Average velocity & $\mathrm{km} / \mathrm{h}$ & 18.7 & 62.6 & 33.6 \\
\hline Maximum velocity & $\mathrm{km} / \mathrm{h}$ & 50 & 120 & 120 \\
\hline
\end{tabular}

If take that:

$\mathrm{FC}_{\mathrm{NEDC}}$ - fuel consumption in NEDC test, $\mathrm{dm}^{3 /} 100 \mathrm{~km}$, $\mathrm{FC}_{\mathrm{UDC}}$-fuel consumption in UDC test, $\mathrm{dm}^{3 /} 100 \mathrm{~km}$, $\mathrm{FC}_{\mathrm{EUDC}}$-fuel consumption in EUDC test, $\mathrm{dm}^{3 /} 100 \mathrm{~km}$, then, taking into consideration the values from the Table 1, the relation is acquired

$$
\mathrm{FC}_{\mathrm{NEDC}}=0.368129 \mathrm{FC}_{\mathrm{UDC}}+0.631871 \mathrm{FC}_{\mathrm{EUDC}}
$$

according to which the value of fuel consumption in the NEDC test may be assigned.

\section{The correlation of the fuel consumption assigned in the driving tests and in the operation of vehicles}

There has been stated that the fuel consumption in operation is significantly higher than the one given in the tests [2, 15-19]. Because this opinion is based on the reports of numerous research centers or the ones who provide vehicles evaluation (like the AMS editorial office) it is necessary to wonder how to lead to consistency of the test data and operation data. 
However, there appears the question whether the correlation of fuel consumption assigned in the tests and in the operation of vehicles may occur at all. Before answering it, there is necessary to pay attention again on the fact that from one side:

- the fuel consumption in the tests is assigned on the way of recalculations, and from the other side,

- the so called operating fuel consumption is assigned in the controlled operation.

Additional doubt which appears, concerns whether the measurements in the controlled operation may be authoritative for the evaluation of fuel consumption in the natural operation. Here, the future works are continuing, but in this moment the data from the controlled operation are taken for the further considerations.

Due to the fact that the present paper concerns presentation of the results correlation method, the data available in the literature will be used in its further part. There has been used the data presented by the editorial office of Auto Motor und Sport. The editorial office leads the usage measurement on chosen test fragments assigning $\mathrm{OFC}_{\mathrm{AMS}}$ and $\mathrm{OFC}_{\mathrm{AMSS}}$

Subsequently, $\mathrm{OFC}_{\mathrm{AMS}}$ was treated as the equivalent of $\mathrm{FC}_{\mathrm{UDC}}$ from the UDC test, whereas $\mathrm{OFC}_{\mathrm{Amss}}$ as the equivalent of $\mathrm{FC}_{\mathrm{EUDC}}$ from EUDC tests.

Hence, there has been assumed, that the fuel consumption in controlled operation OFCs will be indicated from the relation

$$
\mathrm{OFC}_{\mathrm{S}}=0.368129 \mathrm{OFC}_{\mathrm{AMS}}+0.631871 \mathrm{OFC}_{\mathrm{AMSS}}
$$

If take that the operating fuel consumption is to be correlated with the test consumption then

$$
\begin{gathered}
0.368129 \mathrm{OFC}_{\mathrm{AMS}}+0.631871 \mathrm{OFC}_{\mathrm{AMSS}}=\mathrm{OFC}_{\mathrm{S}}= \\
=\mathrm{b}_{0}+\mathrm{b}_{1} * \mathrm{FC}_{\mathrm{UDC}}+\mathrm{b}_{2} * \mathrm{FC}_{\mathrm{EUDC}}
\end{gathered}
$$

As it is visible on the right side of the equation (9) there does not exist the right side of the equation (7). It has been assumed, that there is no premise to stick to the formula (7) resulting from the Table 1 which means that the NEDC test should consist of UDC test plus EUDC test, however, is does not have to be the four times repetition of UDC test plus one repetition of EUDC test.

The usefulness of the assumption according to (9) has been checked by the use of operating data presented by AMS.

The editorial office of the AMS has carried out the measurements of both: cars driven by the spark ignition engines (OTTO), as well as the vehicles with compression ignition engines (DIESEL)

Both entry data and the calculation results are gathered in the tables.

The $\mathrm{OFC}_{\mathrm{SC}}$ values ( the calculated operating fuel consumption) has been determined from the dependence

$\mathrm{OFC}_{\mathrm{SC}}=0.440043 \mathrm{FC}_{\mathrm{UDC}}+0.855818 \mathrm{FC}_{\mathrm{EUDC}}-0.12364=$

$$
=\mathrm{NFC}_{\mathrm{NEDC}}
$$

which comes out from the Table 2 data with the use of regression analysis. It is worth to once again pay attention, that in the equation (10) the input data are the values of fuel consumption determined in UDC and EUDC tests, thus in the standard measurement tests. According to this fact the

\begin{tabular}{|c|c|c|c|c|c|c|c|c|c|}
\hline \multirow[t]{2}{*}{ No } & \multirow[t]{2}{*}{ Car (OTTO) } & $\mathrm{FC}_{\mathrm{UDC}}$ & $\mathrm{FC}_{\mathrm{EUDC}}$ & $\mathrm{FC}_{\mathrm{NEDC}}$ & $\mathrm{OFC}_{\mathrm{AMS}}$ & $\mathrm{OFC}_{\mathrm{AMSS}}$ & $\mathrm{OFC}_{\mathrm{s}}$ & $\mathrm{OFC}_{\mathrm{SC}}$ & $\begin{array}{c}\text { Difference } \\
\left(\mathrm{OFC}_{\left.\mathrm{S}^{-}-\mathrm{OFC}_{\mathrm{SC}}\right) /}\right. \\
\mathrm{OFC}_{\mathrm{S}}\end{array}$ \\
\hline & & \multicolumn{7}{|c|}{$\mathrm{dm}^{3} / 100 \mathrm{~km}$} & $\%$ \\
\hline 1 & Focus Turnier 1.6 Titanium & 7.70 & 5.00 & 6.00 & 10.80 & 5.70 & 7.58 & 7.54 & 0.44 \\
\hline 2 & 308 SW 1.6 THP Active & 9.50 & 5.20 & 6.80 & 10.70 & 6.00 & 7.73 & 8.51 & -10.05 \\
\hline 3 & Astra Sports Tourer 1.4 Turbo & 8.40 & 4.90 & 6.10 & 11.10 & 6.40 & 8.13 & 7.77 & 4.48 \\
\hline 4 & Twingo 1.2 16V Access & 6.70 & 4.20 & 5.10 & 8.80 & 4.80 & 6.27 & 6.42 & -2.34 \\
\hline 5 & i10 1.1 Base & 5.80 & 4.10 & 4.70 & 8.40 & 4.60 & 6.00 & 5.94 & 1.02 \\
\hline 6 & Alto 1.0 Classic & 5.50 & 3.80 & 4.40 & 8.10 & 4.60 & 5.89 & 5.55 & 5.77 \\
\hline 7 & M5 & 14.00 & 7.60 & 9.90 & 18.90 & 9.60 & 13.02 & 12.54 & 3.70 \\
\hline 8 & E 63 AMG & 13.80 & 7.50 & 9.80 & 18.40 & 9.70 & 12.90 & 12.37 & 4.15 \\
\hline 9 & Panamera Turbo & 17.00 & 8.40 & 11.50 & 22.50 & 9.50 & 14.29 & 14.55 & -1.82 \\
\hline 10 & 458 Italia & 19.70 & 9.70 & 13.30 & 25.70 & 11.70 & 16.85 & 16.85 & 0.04 \\
\hline 11 & MP4-12C & 18.50 & 7.80 & 11.70 & 23.90 & 9.40 & 14.74 & 14.69 & 0.31 \\
\hline 12 & Golf 1.4 TSI Comfortline & 8.10 & 5.20 & 6.30 & 11.50 & 5.50 & 7.71 & 7.89 & -2.36 \\
\hline 13 & Giulietta 1.4 TB Progression & 7.80 & 4.60 & 5.80 & 11.20 & 5.00 & 7.28 & 7.25 & 0.51 \\
\hline 14 & Astra 1.4 Turbo Essentia & 7.40 & 4.80 & 5.90 & 10.80 & 5.20 & 7.26 & 7.24 & 0.29 \\
\hline 15 & Roomster 1.2 TSI Roomster & 7.10 & 4.90 & 5.70 & 11.20 & 5.40 & 7.54 & 7.19 & 4.53 \\
\hline 16 & Meriva 1.4 EcotecEssentia & 8.00 & 5.00 & 6.10 & 10.50 & 5.50 & 7.34 & 7.68 & -4.57 \\
\hline 17 & Grand Modus 1.2 TCE Dyna & 7.60 & 5.00 & 5.90 & 10.30 & 5.90 & 7.52 & 7.50 & 0.27 \\
\hline 18 & C3 Picasso 1.6 VTi SX Pack & 9.40 & 5.50 & 6.90 & 11.30 & 6.60 & 8.33 & 8.72 & -4.68 \\
\hline 19 & Venga 1.6 CVVT M & 8.40 & 5.80 & 6.70 & 10.20 & 5.80 & 7.42 & 8.54 & -15.05 \\
\hline 20 & Swift 1.2 & 6.10 & 4.40 & 5.00 & 9.00 & 4.90 & 6.41 & 6.33 & 1.30 \\
\hline 21 & $\mathrm{C} 31.4 \mathrm{VTi}$ & 7.60 & 4.80 & 5.80 & 9.60 & 5.20 & 6.82 & 7.33 & -7.46 \\
\hline 22 & Ibiza 1.4 MPi & 8.00 & 4.70 & 5.90 & 9.90 & 5.30 & 6.99 & 7.42 & -6.09 \\
\hline 23 & i20 1.2 & 6.50 & 4.30 & 5.10 & 8.90 & 5.60 & 6.81 & 6.42 & 5.84 \\
\hline 24 & Focus 1.6 Ti-VCT 16V Trend & 8.70 & 5.40 & 6.60 & 11.90 & 6.60 & 8.55 & 8.33 & 2.63 \\
\hline 25 & Bravo 1.4 MultiAirDynamic & 7.30 & 4.80 & 5.70 & 12.30 & 5.70 & 8.13 & 7.20 & 11.48 \\
\hline 26 & i30 1.6 Comfort. & 8.00 & 5.20 & 6.20 & 11.60 & 6.00 & 8.06 & 7.85 & 2.66 \\
\hline
\end{tabular}
fuel consumption $\mathrm{NFC}_{\mathrm{NEDC}}$ can be treated as the fuel consumption in the "newer" NEDC test.

Table 2. The measurements and calculation results of fuel consumption in the braking and route tests of vehicles with spark ignition engines (Otto) 
There have been obtained surprisingly good factors of equation (10) prediction, which is testified by its regression statistics.

Table 3. Regression statistics of the equation (12) in relation to fuel consumption model of cars with spark ignition engines

\begin{tabular}{|l|r|}
\hline Multiple of R & 0.989330 \\
\hline Square of R & 0.978775 \\
\hline Matched square of R & 0.976929 \\
\hline Standard error & 0.452155 \\
\hline Observations & 26 \\
\hline
\end{tabular}

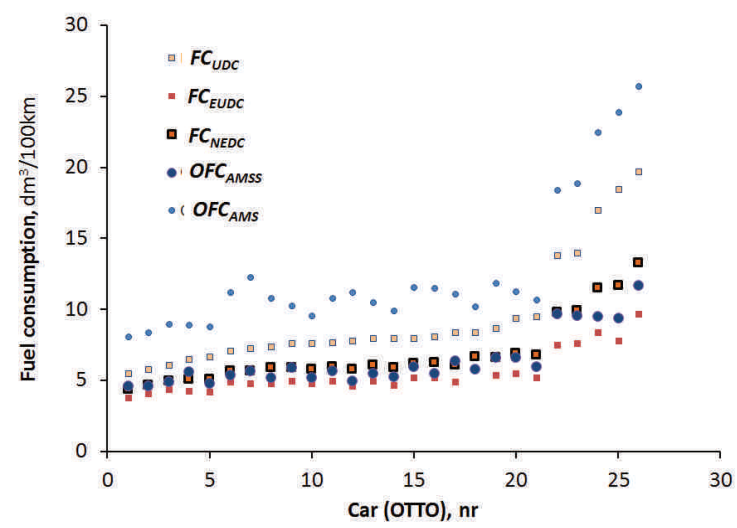

Fig. 4. The research results of fuel consumption in bench tests $\left(\mathrm{FC}_{\mathrm{NEDC}}\right.$, $\mathrm{FC}_{\mathrm{EUDC}}$ and $\left.\mathrm{FC}_{\mathrm{UDC}}\right)$ and in controlled operating tests $\left(\mathrm{OFC}_{\mathrm{AMS}}, \mathrm{OFC}_{\mathrm{AMSS}}\right)$ of vehicles with spark ignition engines

You can see large variances in the results of the tests and those listed in the pilot operation.

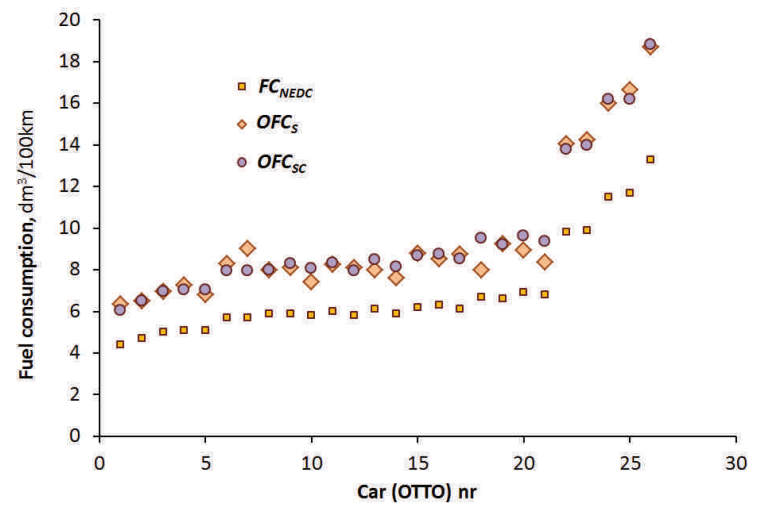

Fig. 5. Fuel consumption $\mathrm{FC}_{\mathrm{NEDC}}$ and in the road tests $\mathrm{OFC}_{\mathrm{S}}$ of vehicles with spark ignition engines

The results obtained in the NEDC test are still different from the operational ones, but if you use the (10) type formula, then the UDC and EUDC (as the newer NEDC test) and the results from the controlled operation almost overlap.

Similar results were obtained in case of vehicles powered by compression ignition engines (diesel).

In the case of vehicles powered by the compression ignition engines (Diesel) there has been also obtained the dependence (11)

$$
\begin{aligned}
& \mathrm{OFC}_{\mathrm{SC}}=-0.012954 \mathrm{FC}_{\mathrm{UDC}}+0.964301 \mathrm{FC}_{\mathrm{EUDC}}+2.466235= \\
&= \mathrm{NFC}_{\mathrm{NEDC}}
\end{aligned}
$$

Analyzing the abovementioned equation there can be stated that in the case of vehicles with compression ignition engines (DIESEL) the fuel consumption assigned in the urban test (UDC) is particularly irrelevant. The essential value is the fuel consumption assigned in the EUDC test.

Also in this case, the obtained prediction factors were not bad (however, they were worse that in the case of vehicles powered by spark ignition engines).

Table 5. Regression statistics of the equation (13) in reference to fuel consumption model of cars with compression ignition engines

\begin{tabular}{|l|r|}
\hline Multiple of R & 0.851541 \\
\hline Square of R & 0.725122 \\
\hline Matched square of R & 0.712628 \\
\hline Standard error & 0.516375 \\
\hline Observations & 47 \\
\hline
\end{tabular}

The data from the abovementioned tables are illustrated in the diagrams.

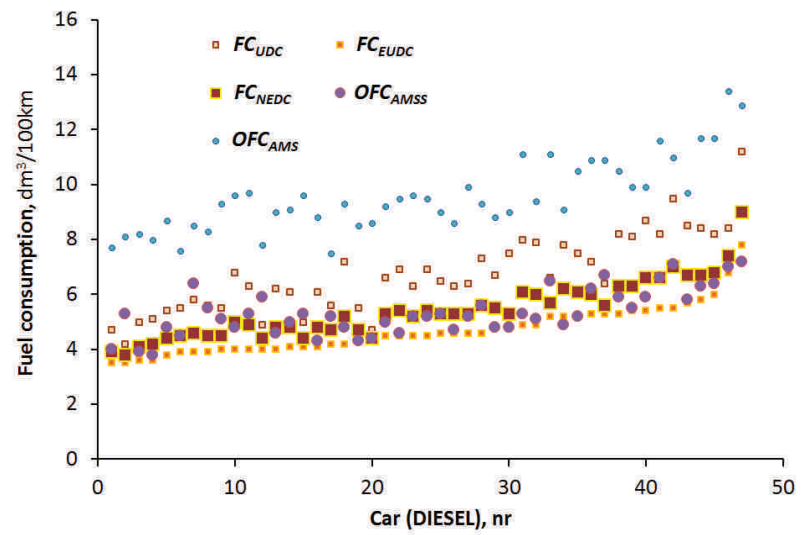

Fig. 6. The research results of fuel consumption in bench tests $\left(\mathrm{FC}_{\mathrm{NEDC}}\right.$, $\mathrm{FC}_{\mathrm{EUDC}}$ and $\left.\mathrm{FC}_{\mathrm{UDC}}\right)$ and in controlled operating tests $\left(\mathrm{OFC}_{\mathrm{AMS}}, \mathrm{OFC}_{\mathrm{AMSS}}\right)$ of vehicles with compression ignition engines (DIESEL's)

As with OTTO engines, vehicles with Diesel engines also exhibit a fuel consumption balance in tests and in controlled operation.

After the conversion according to the formula (11), the correlation of the results was significantly improved.

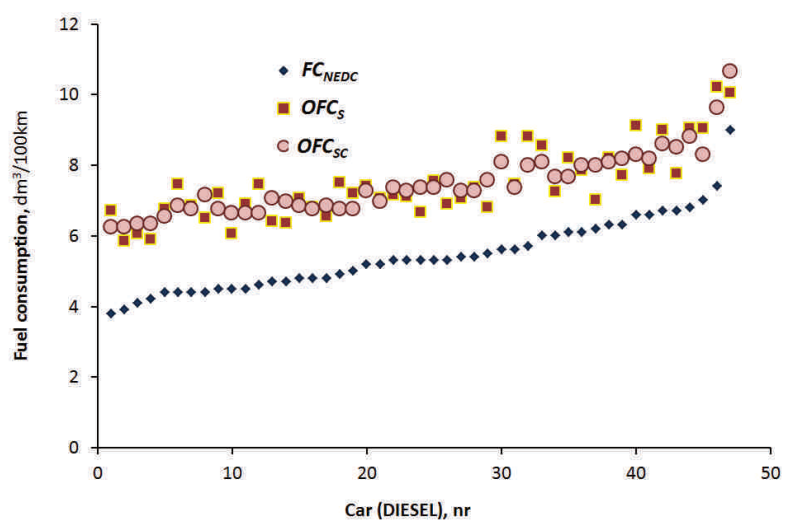

Fig. 7. Correlation of fuel consumption $\mathrm{FC}_{\mathrm{EUDC}}$ and in road test $\mathrm{OFC}_{\mathrm{S}}$ and calculated $\mathrm{OFC}_{\mathrm{SC}}$ of vehicles with compression ignition engines (DIESEL's) 
Table 4. Data concerning fuel consumption in the cars with compression ignition engines (diesel)

\begin{tabular}{|c|c|c|c|c|c|c|c|c|c|}
\hline \multirow[t]{2}{*}{ No } & \multirow[t]{2}{*}{ Car(DIESEL) } & $\mathrm{FC}_{\mathrm{UDC}}$ & $\mathrm{FC}_{\text {EUDC }}$ & $\mathrm{FC}_{\mathrm{NEDC}}$ & $\mathrm{OFC}_{\mathrm{AMS}}$ & $\mathrm{OFC}_{\mathrm{AMSS}}$ & $\mathrm{OFC}_{\mathrm{S}}$ & $\mathrm{OFC}_{\mathrm{SC}}$ & \multirow{2}{*}{$\begin{array}{c}\text { Difference } \\
\left(\mathrm{OFC}_{\mathrm{S}}-\mathrm{OFC}_{\mathrm{SC}}\right) / \\
\mathrm{OFC}_{\mathrm{S}} \\
\%\end{array}$} \\
\hline & & \multicolumn{7}{|c|}{$\mathrm{dm}^{3} / 100 \mathrm{~km}$} & \\
\hline 1 & A1 1.6 TDI Ambition & 4.70 & 3.50 & 3.90 & 7.70 & 4.00 & 5.36 & 5.78 & -7.80 \\
\hline 2 & Cooper D & 4.20 & 3.50 & 3.80 & 8.10 & 5.30 & 6.33 & 5.79 & 8.59 \\
\hline 3 & 320d Efficient Dynamics Edition & 5.00 & 3.60 & 4.10 & 8.20 & 3.90 & 5.48 & 5.87 & -7.11 \\
\hline 4 & Polo 1.6 TDI Highline & 5.10 & 3.60 & 4.20 & 8.00 & 3.80 & 5.35 & 5.87 & -9.83 \\
\hline 5 & B $180 \mathrm{CDI}$ & 5.40 & 3.80 & 4.40 & 8.70 & 4.80 & 6.24 & 6.06 & 2.81 \\
\hline 6 & Astra Sports Tourer 1.7 CDTI Enjoy & 5.50 & 3.90 & 4.50 & 7.60 & 4.50 & 5.64 & 6.16 & -9.12 \\
\hline 7 & C4 1.6 e-HDiExclusive & 5.80 & 3.90 & 4.60 & 8.50 & 6.40 & 7.17 & 6.15 & 14.24 \\
\hline 8 & DS3 HDI 110 SportChic & 5.60 & 3.90 & 4.50 & 8.30 & 5.50 & 6.53 & 6.15 & 5.76 \\
\hline 9 & Zafira Tourer 2.0 CDTiEcoflex Cosmo & 5.50 & 4.00 & 4.50 & 9.30 & 5.10 & 6.65 & 6.25 & 5.93 \\
\hline 10 & 508 SW 2.0 HDiAllure & 6.80 & 4.00 & 5.00 & 9.60 & 4.80 & 6.57 & 6.24 & 5.05 \\
\hline 11 & Insignia 2.0 CDTI Eco-FLEX Cosmo & 6.30 & 4.00 & 4.90 & 9.70 & 5.30 & 6.92 & 6.24 & 9.80 \\
\hline 12 & Cee'd 1.6 CRDi M & 4.90 & 4.00 & 4.40 & 7.80 & 5.90 & 6.60 & 6.26 & 5.14 \\
\hline 13 & C 220 CDI Avantgarde & 6.20 & 4.00 & 4.80 & 9.00 & 4.60 & 6.22 & 6.24 & -0.38 \\
\hline 14 & Jetta 2.0 TDI CR Highline & 6.10 & 4.10 & 4.80 & 9.10 & 5.00 & 6.51 & 6.34 & 2.59 \\
\hline 15 & C-Max 1.6 TDCiTitanium & 5.00 & 4.10 & 4.40 & 9.60 & 5.30 & 6.88 & 6.36 & 7.67 \\
\hline 16 & Golf 2.0 TDI CR Trendline & 6.10 & 4.10 & 4.80 & 8.80 & 4.30 & 5.96 & 6.34 & -6.45 \\
\hline 17 & Auris 1.4 D-4D Premium & 5.60 & 4.20 & 4.70 & 7.50 & 5.20 & 6.05 & 6.44 & -6.57 \\
\hline 18 & S60 D3 Summum & 7.20 & 4.20 & 5.20 & 9.30 & 4.80 & 6.46 & 6.42 & 0.52 \\
\hline 19 & i40 1.7 CRDi Premium & 5.50 & 4.30 & 4.70 & 8.50 & 4.30 & 5.85 & 6.54 & -11.89 \\
\hline 20 & Countryman Cooper D & 4.70 & 4.40 & 4.40 & 8.60 & 4.40 & 5.95 & 6.65 & -11.81 \\
\hline 21 & Grand C-Max 2.0 TDCi Titanium & 6.60 & 4.50 & 5.30 & 9.20 & 5.00 & 6.55 & 6.72 & -2.66 \\
\hline 22 & 6 Kombi 2.2 MZR-CD Kirei & 6.90 & 4.50 & 5.40 & 9.50 & 4.60 & 6.40 & 6.72 & -4.88 \\
\hline 23 & Passat 2.0 TDI CR Comfortline & 6.30 & 4.50 & 5.20 & 9.60 & 5.20 & 6.82 & 6.72 & 1.40 \\
\hline 24 & 6 Kombi 2.2 MZR-CD Sport & 6.90 & 4.50 & 5.40 & 9.50 & 5.20 & 6.78 & 6.72 & 0.98 \\
\hline 25 & Touran 2.0 TDI Highline & 6.50 & 4.60 & 5.30 & 9.00 & 5.30 & 6.66 & 6.82 & -2.34 \\
\hline 26 & Passat 2.0 TDI DSG Comfortline & 6.30 & 4.60 & 5.30 & 8.60 & 4.70 & 6.14 & 6.82 & -11.16 \\
\hline 27 & Mondeo 2.0 TDCi Trend & 6.40 & 4.60 & 5.30 & 9.90 & 5.20 & 6.93 & 6.82 & 1.60 \\
\hline 28 & Altea 2.0 TDI CR Style & 7.30 & 4.60 & 5.60 & 9.30 & 5.60 & 6.96 & 6.81 & 2.22 \\
\hline 29 & Lancer 1.8 DI-D Intense & 6.70 & 4.80 & 5.50 & 8.80 & 4.80 & 6.27 & 7.01 & -11.73 \\
\hline 30 & SuperbCombi 2.0 TDI Elegance & 7.50 & 4.80 & 5.30 & 9.00 & 4.80 & 6.35 & 7.00 & -10.27 \\
\hline 31 & E 250 CDI Kombi & 8.00 & 4.90 & 6.10 & 11.10 & 5.30 & 7.44 & 7.09 & 4.67 \\
\hline 32 & Insignia Sports Tourer 2.0 CDTi Cosmo & 7.90 & 4.90 & 6.00 & 9.40 & 5.10 & 6.68 & 7.09 & -6.08 \\
\hline 33 & 530d xDrive & 6.60 & 5.20 & 5.70 & 11.10 & 6.50 & 8.19 & 7.40 & 9.74 \\
\hline 34 & Superb 2.0 TDI DSG 4x4 Comfort & 7.80 & 5.20 & 6.20 & 9.10 & 4.90 & 6.45 & 7.38 & -14.48 \\
\hline 35 & SuperbCombi 2.0 TDI CR & 7.50 & 5.20 & 6.10 & 10.50 & 5.20 & 7.15 & 7.38 & -3.25 \\
\hline 36 & A6 3.0 TDI Quattro & 7.20 & 5.30 & 6.00 & 10.90 & 6.20 & 7.93 & 7.48 & 5.63 \\
\hline 37 & X3 xDrive20d. & 6.40 & 5.30 & 5.60 & 10.90 & 6.70 & 8.25 & 7.49 & 9.12 \\
\hline 38 & Laguna $2.0 \mathrm{dCi} 175$ aut. Bose Edition & 8.20 & 5.30 & 6.30 & 10.50 & 5.90 & 7.59 & 7.47 & 1.61 \\
\hline 39 & Laguna Grandtour 2.0 dCiDynamique & 8.10 & 5.40 & 6.30 & 9.90 & 5.50 & 7.12 & 7.57 & -6.30 \\
\hline 40 & $30082.0 \mathrm{HDi}$ aut. Premium+ & 8.70 & 5.40 & 6.60 & 9.90 & 5.90 & 7.37 & 7.56 & -2.55 \\
\hline 41 & E 350 CDI 4Matic & 8.20 & 5.50 & 6.60 & 11.60 & 6.60 & 8.44 & 7.66 & 9.21 \\
\hline 42 & XC60 D5 AWD & 9.50 & 5.50 & 7.00 & 11.00 & 7.10 & 8.54 & 7.65 & 10.41 \\
\hline 43 & Qashqai 2.0 dCiVisia & 8.50 & 5.70 & 6.70 & 9.70 & 5.80 & 7.24 & 7.85 & -8.53 \\
\hline 44 & GLK 220 CDI 4MATIC & 8.40 & 5.80 & 6.70 & 11.70 & 6.30 & 8.29 & 7.95 & 4.07 \\
\hline 45 & Q5 2.0 TDI Quattro & 8.20 & 6.00 & 6.80 & 11.70 & 6.40 & 8.35 & 8.15 & 2.46 \\
\hline 46 & ML 350 BlueTEC & 8.40 & 6.80 & 7.40 & 13.40 & 7.00 & 9.36 & 8.91 & 4.72 \\
\hline 47 & FX30d & 11.20 & 7.80 & 9.00 & 12.90 & 7.20 & 9.30 & 9.84 & -5.85 \\
\hline
\end{tabular}

\section{Conclusions}

There exists the urgent need to limit the carbon dioxide emission coming from motorization, and the simplest way to obtain this aim is lowering of operating fuel consumption. There has been noticed, that throughout the last years the reduction of carbon dioxide emission determined in the bench tests was achieved, however, it is not reflected in the natural operation of vehicles. The causes of this state may be found mainly in incompatibility between test conditions and actual vehicles operating conditions.

This article has risen to this issue, concurrently proposing the way of solving the problem.

There has been noticed, that in order to limit the increase of carbon dioxide concentration in the atmosphere, it is necessary to limit the fuel consumption. Therefore, there has been suggested the different attitude to fuel consumption determining in the natural operation, and also broader employing of test data in order to reach the correlation between test and operation fuel consumption.

The appropriate calculating procedure has been proposed.

It has been shown that:

- The results of controlled operating of vehicles may be presented in different form referring to the results of UDC, EUDC or NEDC tests researches.

- The results of fuel consumption researches obtained in the controlled operation of vehicles conditions are possible to correlate with the results of bench test researches.

- There exists satisfactory correlation of fuel consumption research results, determined in the controlled operation 
with the results of bench tests- urban UDC and out of city EUDC.

- Because the results of fuel consumption test researches come from the calculations arising from fumes components concentrations, and not directly from the measurements, it seems to be deliberate to implement the further calculating procedures e.g., according to the conception included in this paper, in a way to obtain the correlation of bench tests results with operation researches results.

- The implementation of procedures would enable the real evaluation of operating fuel consumption on the basis standard test researches, without the necessity of change the tests themselves, especially the ones coming in like e.g. WLTP.

- It is deliberate to carry on the further works targeting at reliable fuel consumption evaluation obtaining in natural operation of vehicles and their correlation with bench tests results

The presented research results have been based on relatively sparing experimental references. To broaden the resource of experiment, the continuation of researches seems to be necessary, especially due to the fact, that a new kind of bench test - WLTP is going to be implemented.

\section{Nomenclature}

$\mathrm{CO}$ planned carbon oxide emission

$\mathrm{CO}_{2} \quad$ planned carbon dioxide emission

CNG compressed natural gas

D density of the used fuel

DIESEL compression ignition engine

EUDC extra urban driving cycle

FC fuel consumption

$\mathrm{FC}_{\text {EUDC }}$ fuel consumption in EUDC test

$\mathrm{FC}_{\mathrm{NEDC}}$ fuel consumption in NEDC test

$\mathrm{FC}_{\mathrm{UDC}}$ fuel consumption in UDC test
LPG liquified petrolum gas

NEDC new European driving cycle

$\mathrm{NG}$ natural gas

$\mathrm{OFC}_{\mathrm{m}} \quad$ average, operational fuel consumption

$\mathrm{OFC}_{\mathrm{sm}}$ corresponding $\mathrm{S}_{\mathrm{m}}$, operational fuel consumption

OTTO spark ignition engine

$\mathrm{S}_{\mathrm{m}} \quad$ vehicle mileage. $\mathrm{km}$,

THC planned hydrocarbon emission

UDC urban driving cycle

\section{Bibliography}

[1] TIETGE, U., DÍAZ, S., MOCK, P. et al. From laboratory to road. A 2016 update of official and 'real-world' fuel consumption and $\mathrm{CO}_{2}$ values for passenger cars in Europe. White Paper. November 2016, www.theicct.org.

[2] DUDENHÖFFER, F., JOHN, E-M. Studie Kraftstoffverbrauch. Warum der offizielle Kraftstoffverbrauch von Neuwagen erheblich von der Realität abweicht. ÖkoGlobeInsituts der Universität Duisburg-Essen. 2009.

[3] SITNIK, L.J. Theory of cumulative fuel consumption by LPG powered cars. Journal of KONES. 2015, 22(4), 275-280.

[4] DIMITROV, R., MAGDZIAK-TOKŁOWICZ, M., SITNIK, L.J. et al. A comparison of fuel consumption between the new European driving cycle test and the natural operation of a vehicle. MTM Machines, Technologies, Materials. 2014, $\mathbf{8}(2), 23-25$.

[5] SITNIK, L.J. Theory of cumulative fuel consumption and example for its application. Trans \& MOTAUTO' 14: XXII international scientific-technical conference: proceedings. Section I, Vehicle engines. Application of fuels types. Efficiency. Scientific-technical union of mechanical engineering, 2014, 17-20.

[6] SITNIK, L.J., MAGDZIAK-TOKŁOWICZ, M., WALKOWIAK, W.W. et al. Comparison of mileage fuel consumption with the natural operation of the three different cycles. Journal of KONES. 2014, 21(4), 439-444.

[7] SITNIK, L.J. Teoria skumulowanego zużycia paliwa i jej aplikacja. Transport Przemystowy i Maszyny Robocze. 2014, 2, 116-121.

[8] SKRĘTOWICZ, M.D., SITNIK, L.J., KAŹMIERCZAK, A., MAGDZIAK-TOKŁOWICZ, M. Evaluation methods of the impact of motorization on the quality of the atmospheric air. Journal of KONES. 2014, 21(4), 445-452.

[9] KARDASZ, P.Ł. SITNIK, L.J., SZUBERSKI, K., HALLER, P. Ekologiczne skutki motoryzacji. Autonaprawa. 2010, 9, 22-24.
[10] SITNIK, L.J. Some aspect of theory of cumulated fuel consumption. Journal of KONES. 2010, 17(4), 447-453.

[11] SITNIK, L.J. Analiza przebiegów do wymiany oleju silnikowego w eksploatacji naturalnej samochodów. Journal of KONES. 2009, 16(3), 367-373.

[12] SITNIK, L.J. Statystyczna weryfikacja osiagów silników spalinowych. Journal of KONES. 2006, 13(4), 175-182.

[13] SITNIK, L.J. Skumulowane zużycie paliwa. Archiwum Motoryzacji. 2004, 7(3), 227-254.

[14] Testy porównawcze www.auto-motor-i-sport.pl/testy/testyporownawcze.html.

[15] Spritverbrauch: Herstellerangabe gegen Test - Autobild www.autobild.de/artikel/spritverbrauch-herstellerangabegegen-test-1129421.html.

[16] Test: Kraftstoffverbrauch höher als von Herstellern angegeben www.ace.de/der-club/news/test-kraftstoffverbrauchhoeher-als-von-herstellern-angegeben.html?no_cache $=1$.

[17] Reale Verbrauchsmessungen Spritverbrauch im Labor und in der Realität www.vcd.org/themen/auto-umwelt/realeverbrauchsmessungen/.

[18] Vor dem Autokauf den realen Kraftstoffverbrauch ermitteln kurier.at/motor/vor-dem-autokauf-den-realen-kraftstoffverbrauch-ermitteln/253.857.177.

[19] SpritverbrauchDie große Verbrauchs-Lüge: So stehlen Ihnen Autohersteller 450 Euro pro Jahr www.focus.de/auto/news/ kraftstoffverbrauch-die-grosse-verbrauchs-luege-so-stehlenihnen-autohersteller-450-euro-pro-jahr_id_4168530.html.

Prof. Lech J. Sitnik, DSc., DEng. - Department Vehicles Engineering at Wroclaw University of Science and Technology.

e-mail:Lech.Sitnik@pwr.edu.pl

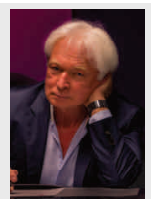

